\title{
Effects of accounts Payable as Source of Financing on Performance of Listed Manufacturing Firms at the Nairobi Securities Exchange
}

\author{
${ }^{1}$ Benjamin Malingu Achode, ${ }^{2}$ Gladys Rotich (PHD) \\ Jomo Kenyatta University of Agriculture and Technology
}

\begin{abstract}
When firms are incorporated, equity capital is the most available source from the promoters. Equity financing consist of ordinary share capital, preference shares, and retained earnings. As business improves, additional capital may be required and debt option is usually the fastest given there are fewer regulatory barriers. In the recent years the performance of some companies listed at the NSE, has been dismal due to their high level of debt compared to equity. The objective of this research was to assess the effects of accounts payable on financial performance of publicly listed manufacturing companies at NSE, Kenya. Census sampling technique was used and the study used secondary data, which was obtained from the companies' statistics and journals at the Nairobi Securities Exchange. SPSS was used to carry out the descriptive analysis of the variables, requisite analysis and advanced analysis of the data. A multiple regression model was used to test the relationship between the Accounts payable and firm performance. The results from this research suggested that in most of the manufacturing firms listed at the NSE, there was a direct positive relationship between Accounts Payable and the dependent variable, Profitability and Liquidity, supporting the Pecking Order Theory.
\end{abstract}

Keywords: Accounts Payable, Firm performance and Debt Financing.

\section{INTRODUCTION}

Two major sources are available for firms willing to raise funds for their activities. These sources are internal and external sources. Saleemi, (2009) defines external financing as that part of the total debt in a business that is owed to outsiders. The internal source refers to the funds generated from within an enterprise which is mostly retained earnings. Retained earnings results from success enterprises earn from their activities. External sources of financing include bank loans, sale of a part of the business to investors (e.g., venture capital firms), grants and leasing (long-term renting of equipment) Pandey, (2005).

According to Harash, Al-Timim, and Alsaadi, (2014), access to finance is essential to the survival and performance of any firm. Access to external finance is a key determinant of a firm's ability to develop, operate and expand (Lopez, 2007). No business can survive without enough funds for working capital, fixed assets investment, employment of skilled employees, development of markets and new products. An optimal capital structure is the best debt/equity ratio of a firm, which minimizes the cost of financing and maximizes the value of the firm.

Debt could be attained in many different ways, and another common way of categorizing debt is based on its different maturities. There are short-term debt, long-term debt and convertible debt. Short-term debt is found under current liabilities on the balance sheet. This could be short-term bank loans, but also longer-term loans that are due within one year, as well as other outstanding debt maturing within a year. When determining a firm's financial health, the current liability account should not exceed the amount of cash and cash equivalents available in the firm, since this will mean that the firm cannot meet its current obligations.

Short term finance is available for a shorter period of time, usually less than one year. It is required for the purchase of working capital assets and for meeting day to day working requirements (Shawn, 2009). Sources of short term finance include trade credit, overdrafts, cash credits, loans, and discounting of bills. Long term finance is available for an extended period of time of over one year. Long term finance is needed for investment in fixed assets such as land and buildings, plant and 
machinery and for financing expansion programmes. Sources of long-term finance include shares, venture capital, grants, retained profits, long-term loans and sale of assets, (Pandey, 2005).

The manufacturing sector in Kenya constitutes 70 per cent of industrial sector contribution to GDP, with building, construction, mining and quarrying cumulatively contributing the remaining 30 per cent (GOK, 2013). The sector grew by 3.1 per cent in 2012.The sector value added improved from Kshs 292.4 billion in 2011 to Kshs 316.7 billion in 2012. The number of wage employment in the sector increased from 276,900 employees in 2011 to 277,900 employees in 2012. The role of the manufacturing sector in Kenya's Vision 2030 is to create employment and wealth. The sectors overall goal is to increase its contribution to GDP by at least 10\% per annum as envisaged in the Vision 2030.

\section{Statement of the Problem}

When firms are incorporated, equity capital is the most available source from the promoters (Abor, 2005). Equity financing consist of ordinary share capital, preference shares, and retained earnings. As business improves, additional capital may be required and debt option is usually the fastest given there are fewer regulatory barriers (Abor, 2005). According to Migiro, (2005), term loans are the most popular form of debt capital among manufacturing firms in Kenya.

In the recent years the performance of some companies listed at the NSE has been dismal due to their high level of debt compared to equity (Chebii, Kipchumba \& Wasike, 2011). For example, the financial statement of Eveready East Africa Limited (2012) shows that the total equity capital was Kshs 349.5 Million but the total short term liabilities, comprising bank loan, trade and other accounts payable and bank overdraft all added up to Kshs 695.8 Million, implying short-term debt capital was 99\% above equity capital. This was before considering non-current staff retirement obligations amounting to Kshs 68.0 Million. In year 2011, the company's short-term debt capital was $133 \%$ above equity capital.

The financial statement of Uchumi Supermarket Limited and Subsidiaries ( 2013), shows that the total for term loan, trade and other payables and bank overdraft was Kshs 2,619 Million compared to total equity capital of Kshs 2,925 Million (Uchumi Supermarket Financial report 2013), giving a debt to equity capital ratio of 0.9:1. Likewise, the financial statements of Mumias Sugar Company Limited (2013) reveal that the equity capital, borrowings (both current and non-current bank loans) and trade and other payables were Kshs 13,289, 6,039 and 4,845 Billions, respectively. From these numbers, total debt capital of Kshs 10,884 billion was $81 \%$ of the company's equity capital.

Literature on external sources of financing has largely focused on the relationship between firm capital structure and performance of the company. For example, Mwangi, Makau and Kosimbei, (2014) studied the relationship between Capital Structure and Performance of Non- Financial Companies Listed in the Nairobi Securities Exchange, Kenya. The results revealed that financial leverage had a statistically significant negative association with performance as measured by return on assets (ROA) and return on equity (ROE). This compares to Addae, Nyarko-Baasi and Hughes,(2013) which mapped capital structure and profitability of listed firms in Ghana and found that there was no conclusive evidence of what should be the optimal capital. On the other hand analysis of financial performance has been severally linked to customer satisfaction as found in the studies by Vandermerwe (2000), Fredericks, (2001) and Reichheld, (2004). Another study by Neokosmidi, (2005) linked market share to financial performance. However, not much local literature has discussed the relationship between individual components of external sources of financing and financial performance, especially of publicly listed manufacturing sector at NSE, Kenya.

\section{OBJECTIVES OF THE STUDY}

To determine the effect of accounts payable financing on financial performance of manufacturing firms listed at the Nairobi Securities Exchange.

The study on accounts payable was guided by research question: To what extent does accounts payable affect the financial performance of manufacturing firms listed at the Nairobi Securities Exchange? 


\section{LiterATURE REVIEW}

A number of classical capital structure theories were reviewed in light of the study variable, with Pecking Order Theory and Trade-off Theory to guide the research. Gordon Donaldson (1961) was one of the first to suggest the thoughts behind the pecking order theory. He found that managers prefer to use internal means for financing. He also stated that debt capacity is limited and that debt increases bankruptcy risk. Donaldson (1961 \& 1969) discussed the principles of the Pecking Order (PO) financing theory. Myers and Majluf (1984) and Myers (1984) further build on these ideas and suggest that firms use a financing hierarchy. Issuing equity is the least preferred type of financing, due to asymmetric information. Accounts payable is preferred to equity issue because it contains lower information costs.

The trade-off theory of financial leverage that was first formulated by Kraus and Litzenberger in 1973 indicates that the increase in accounts payable level will increase the cost of bankruptcy, financial distress and agency, hence decrease the value of the company. The trade-off theory describes how firms choose their optimal capital structure. The nature of this theory is the trade-off between benefits and costs of payables as a debt instrument.

Hassan, U. H., Imran M. M., Amjad M., \& Hussain M., 2014, defines accounts payable as the supplier whose payment for goods or services has been processed but who has not yet been paid. Accounts payable includes trade credit and accrued expenses which together provide finance to the operations of a business on an on-going basis. Firms would rather sell for cash than on credit, but competitive pressure forces most companies to offer trade credits. Unlike credit from financial institutions, trade credit does not rely on formal collateral but on trust and reputation (Fafchamps, 1999).

In order to measure the impact of accounts payable to firm performance in this study, the ratios used included Accounts Payable Turnover ratio, Payables to Net Profit Margin ratio and Payables to Assets ratio. The Accounts Payable Turnover Ratio measures the number of times Accounts Payable is turned over during a time period. The accounts payables to net profit margin ratio measures account payables relative to profit margin, while accounts payables to assets ratio analyses the proportion of assets financed by accounts payable.

The formula to measure Accounts Payable Turnover Ratio is given by Cost of Goods Sold divided by Inventory. To calculate the Accounts Payable Days the formula is 365 days divided by Accounts Payable Turnover Ratio. The accounts payable turnover ratio is a liquidity ratio that shows a company's ability to pay off its accounts payable by comparing net credit purchases to the average accounts payable during a period.

In this research, Payables turnover ratio was measured by dividing cost of goods sold by average inventory at the end of the financial year. Payables to net profit margin ratio was measured by dividing average payables amount by the net profit after tax while Payables to assets ratio was measured by dividing average payables with total assets.

Performance can either be financial or non-financial performance (Ittner, 2008). The non-financial performance is measured using operational Key Performance Indicators such as Market share, innovation rate or customer satisfaction (Hyvonen, 2007). The financial performance is measured using accounting Key Performance Indicators such as Return on assets, Earnings before interest and tax (Crabtree \& DeBusk, 2008).

This study focused on the financial objective based performance measures. The study investigated the financial performance of manufacturing firms listed at NSE. Financial performance was operationalized using the profitability and liquidity measures. There are several measures of profitability which a company can use. Some measures of profitability include Net profit margin, Return on Assets, Return on Equity and Gross Profit Margin, among others.

\section{EMPIRICAL REVIEW}

Nima et al, (2012) examined the relationship between capital structure and firm performance of Tehran Stock Exchange Companies between the years 2006 to 2011. The study reported a significant 
relationship between dependent and independent variable. Similar studies by Ebaid (2009), Nimalathasan, (2010) and Pouraghajan, (2012) found weak-to-no influence, debt was positively and strongly associated with financial performance and significant negative relationship between debt ratio and financial performance, respectively, as measured by profitability. Another similar study by Iorpev and Kwanum, (2012) revealed a negative and insignificant relationship between Short term debt to total assets and Long term debt to total assets, and ROA and profit margin.

Munene, (2011), examined The Effect of Lease Financing on The Financial Performance of Companies Listed at the Nairobi Securities Exchange and found that lease financing and size of the firm had negative effects on ROA while liquidity and leverage had positive effects on ROA. The study concluded that lease financing did not influence the financial performance of listed firms in Kenya. Akinbola, (2012) study found that lease option had positively affected the profit of the SME's as did a similar examination by Salam, (2013) in Bangladesh on the performance of Medium enterprises SMEs.

Malm, and Rosland, (2013), investigated the Bond-to-Total Debt Ratio on Firms' Performance and found an in insignificant relationship between the bond-to-total debt ratio and firm performance. Several researchers have tested the effects of profitability on firm leverage. Kester (1986) and Friend and Lang (1988) concluded that there was a significantly negative relationship between profitability and debt/asset ratios. Rajan and Zingales (1995) and Wald (1999) found a significantly negative relationship between profitability and debt/asset ratios. A similar study by Duyen, (2012) found that short-term debt presents a negative impact on profitability measured by net margin.

While still on research on capital structure Mbugua, (2010) investigated the application of pecking order concept by NSE companies and found that NSE gave priority to internal resources for finance as their total assets' profitability, liquidity levels and sales amounts increased and preferred a lower level of external resource use. The study further revealed that those companies with more internal funds utilized these internal funds to fund their new projects rather than using debt or even equity, while those companies with limited internal funds opted to get debt to fund their projects and if debt was not readily available they opted for equity, thus following the pecking order theory.

Similar studies on capital and firm performance were by: Mwnagi, Makau, and Kosimbei, (2014), who found that financial leverage had a statistically significant negative association with performance as measured by return on assets (ROA) and return on equity (ROE); Siro, (2011), whose findings revealed that there was an inverse relationship between capital structure and financial performance of listed firms in NSE; Leonard, (2014), found that debt and equity were major determinants of financial performance of firms listed at the NSE and there was evidence of a negative and significant relationship between capital structure and all measures of performance, implying that the more debt the firms used as a source of finance they experienced low performance and firms listed at NSE used more short-term debts than long-term debts.

Pratheepkanth, (2011), study found a weak positive relationship between gross profit and capital structure and there was a negative relationship between net profit and capital structure. ROI and ROA also had negative relationship with capital structure at $-0.104,-0.196$ respectively. Kajirwa, (2015), examination revealed that debt negatively affects firm performance of NSE Commercial Banks, though not statistically significant as measured by ROA. Kajananthan \& Nimalthasan (2013) examination indicated that gross profit, net profit, return on equity, return on assets, were not significantly correlated with debt equity ratio and Gross profit margin and Return on equity were significantly correlated with debt assets ratio as the measures of capital structure and capital structure had significant impact on gross profit and return on equity.

Quainoo, (2011) study investigated the impact of loans on SMEs (in Ghana) and found that term loans were the most patronized type of bank loans due their repayment structure which were structured in line with the business cash flows; that most SMEs used loans as working capital mainly to source raw materials for production; that bank loans for SMEs were mostly used improve their performance and that there was a major disadvantage of accessing a bank business loan because of the high cost of capital (usually high interest rate) charged mostly on SMEs.

Charitou et al, (2010), performed a study on the effect of working capital management on firm's financial performance and found that the cash conversion cycle and all its major components; namely, 
days in inventory, days' sales outstanding and accounts payable payment period - were associated with the firm's profitability and that working capital management led to improved profitability.

The prior literature suggests that different debt sources provide different features that may have either good or bad effects on firm performance (Diamond, 1984, 1991; Rajan, 1992). While existing theoretical models suggest that firm value is affected by the particular composition of debt sources (Bolton \& Scharfstein, 1996; Bolton \& Freixas, 2000; Park, 2000), not much research has been carried out on the relationship between firm performance and the various individual components of debt; bond (public), accounts payable, lease finance and bank debt, among others. This study will address this gap and also add literature in capital structure theory by examining the association of individual of components external sources of financing and firm performance for manufacturing firms listed at NSE.

\section{RESEARCH METHODOLOGY}

The study adopted a cross-sectional research design. This is because the study employed quantitative comparison between independent variables and dependent variables and data was collected at a single point in time and more or less simultaneously. Additionally, there are systematic and standardized methods for gauging variables in order to examine relationships between variables and detect patterns of association. Last but not the least, as Bryman \& Bell, 2003, stated "with a cross-sectional design, it is only possible to examine relationship between variables". Since the study was intended to establish the relationship between accounts payables as a source of financing and firm performance, crosssectional design was considered the most suitable for the study.

The population of the study was all manufacturing firms listed at NSE, Kenya as at $31^{\text {st }}$ December 2013. All the firms were considered given they were only 16 units. Secondary data from the financial reports of NSE listed manufacturing companies from the year 2009 through to year 2013 were used because the intention was to give trend analysis over time.

Financial reports of the research companies have been prepared annually and have all been publicized. The financial figures for the period 2009-2013 which were used in this study were gathered manually through individual company financial reports and summarized in excel worksheets. The measure of financial performance was taken as the dependent variable while accounts payable financing, term loan financing, lease financing and bond financing were taken as the independent variables. Collected data was validated, coded and checked for any errors and omissions. Thereafter the data was run through the Statistical Package for Social Science (SPSS) Version 20. The objective was met by computing the regression analysis of the variables. The $\beta$ coefficients were calculated to measure the percentage of debt ratios. ANOVA was used to measure the effect of debt ratio on profitability and liquidity.

\section{RESEARCH FINDINGS AND DISCUSSIONS}

Secondary data was collected from Nairobi Securities Exchange Handbooks and published books of accounts of the companies listed in the Nairobi Securities Exchange. Out of the 16 manufacturing companies listed at the Nairobi Securities Exchange (NSE), this study got data for 15 firms which were considered satisfactory for subsequent analysis. One company, A. Baumann and Company Limited, had been delisted from the NSE as a result of failure to comply with NSE regulations. The data was cleaned, outliers were noted, and scatter diagrams were constructed to test for the outliers. Normal distribution was tested by using Bar Graphs.

Test of fitness showed that the data used for analysis in this research was fit for analysis and the means of the various variables fell within an acceptable range. On the other hand the Standard Deviation was used to measure the spread of the data values. Regression of Accounts Payable on elements of performance showed direct positive correlation, for example, Sameer Africa Limited had a positive Correlation with Current Ratio, Quick ratio, Net Profit Margin and a negative correlation with Gross profit margin. It can also be seen that Accounts Payable had a negative Correlation with the Current Ratio, Quick ratio and Gross Profit at Carbacid Investments Limited. There is a similar trend at E. A Breweries and Kenya Orchards affecting the same dependent variables. 
Table 1.1. Regression coefficients for each company

\begin{tabular}{|c|c|c|c|c|c|}
\hline & \multicolumn{5}{|c|}{ ACCOUNTS PAYABLE COEFFICIENTS } \\
\hline $\begin{array}{c}\text { Marshalls (E.A.) } \\
\text { Ltd }\end{array}$ & -0.639 & -0.359 & -17.095 & $\begin{array}{c}\text { Net Profit } \\
\text { Margin }\end{array}$ & $\begin{array}{c}\text { Return on } \\
\text { Equity }\end{array}$ \\
\hline Sameer Africa Ltd & 1168.63 & 601.453 & -288.816 & 95.802 & - \\
\hline ARM Cement Ltd & $3.985^{*} 10^{-10}$ & 3.157 & 143.049 & 43.951 & 1.675 \\
\hline $\begin{array}{c}\text { Bamburi Cement } \\
\text { Ltd }\end{array}$ & -53.477 & -34.808 & 27.2 & 0.661 & 0.184 \\
\hline $\begin{array}{c}\text { Crown Paints } \\
\text { Kenya Ltd }\end{array}$ & 0.589 & 0.402 & 1.064 & 0.354 & 1.268 \\
\hline E.A.Cables Ltd & 2.032 & -2.286 & 144.993 & 34.301 & 54.571 \\
\hline $\begin{array}{c}\text { E.A.Portland } \\
\text { Cement Co }\end{array}$ & 2.77 & 0.862 & 30.344 & 1.417 & 3.301 \\
\hline B.O.C Kenya Ltd & 25.903 & 19.875 & 4.388 & -0.375 & - \\
\hline B. A. T Kenya Ltd & 7.342 & 4.037 & 3.489 & 0.062 & -0.53 \\
\hline $\begin{array}{c}\text { Carbacid } \\
\text { Investments Ltd }\end{array}$ & -18.977 & -16.701 & -20.124 & 0.839 & - \\
\hline $\begin{array}{c}\text { E. A. Breweries } \\
\text { Ltd }\end{array}$ & -1.568 & -0.356 & -10.036 & 1.504 & 115.813 \\
\hline $\begin{array}{c}\text { Eveready East } \\
\text { Africa Ltd }\end{array}$ & 0.618 & -0.017 & 7.003 & 26.0081 & 148.1 \\
\hline $\begin{array}{c}\text { Kenya Orchards } \\
\text { Ltd }\end{array}$ & -0.205 & -4.439 & -2.103 & 1.605 & 47.282 \\
\hline $\begin{array}{c}\text { Mumias Sugar Co. } \\
\text { Ltd }\end{array}$ & 1.472 & 0.199 & 63.23 & -3.085 & -34 \\
\hline Unga Group Ltd & -0.423 & -2.099 & 17.115 & 2.548 & 12.047 \\
\hline
\end{tabular}

The regression analysis was done in SPSS and the results captured using pie charts, tables, figures and descriptive statistics. In most of the firms, the value of the variable GP\% was found to be high, in a number of cases above 50\%. In this study, the NPM and ROE for some of the firms were negligible values. This study however observed that profitability and liquidity of the firms were dependent on external financing. In some of the firms, where term loans were huge there was a notable low value of NPM, ROE and GP\%. Term loan for Crown Paints Kenya Ltd was 6.7\%, GP\% was $60.7 \%$, Current ratio was $2.5 \%$ and Quick ratio was $1.5 \%$ in comparison to other independent variables. At East African Cables Ltd, term loan was $9.8 \%$ while GP\% was $43.1 \%$, ROE was $14.7 \%$, NPM was $8.8 \%$ and Current Ratio was $1.8 \%$. At Eveready east Africa, ROE was $-17.5 \%$, term loan was $38.7 \%$, GP\% was $50.5 \%$ and NPM was $-3.5 \%$.

\section{SUMMARY OF FINDINGS AND RECOMMENDATIONS}

From the ANOVA analysis, the research findings indicated that there was a strong positive relationship $(\mathrm{R}>=0.7)$ between the independent and dependent variables. The study also revealed that almost $80.0 \%$ of the variance in performance of the manufacturing firms listed at the Nairobi Securities Exchange could be explained by the accounts payable as a source of financing. However, the remaining $20 \%$ could not be explained by these variables. The study noted that the effect of Accounts payable financing on the listed manufacturing firms varied from one firm to another. In some manufacturing firms the effect was huge while in others the effect was negligible. Most of the manufacturing firms with huge accounts payable ratios posted good performance results. For instance, Bamburi Cement Ltd, Payables Turnover ratio was $10.7 \%$ and the corresponding GP\% was $67.3 \%$ and at Carbacid Investments Ltd, Payables turnover ratio was $13.0 \%$ and the GP\% stood at $64.6 \%$. From this study it was evident that at $95 \%$ confidence level, the variables produced statistically significant values (high t-values, $\mathrm{p}<0.05$ ) hence when the variables were combined, they could be relied on to explain capital structure of the firms listed at the Nairobi Securities Exchange. This is in line with Kijirwa, 2015 study that concluded that the use of debt in a firms' capital structure negatively affects a firms' financial performance.

As can be seen from the Summary of the equations of dependent variables from all the firms, the results from this research suggest that in most of the manufacturing firms listed at the NSE, there was 
a direct positive relationship between Accounts Payable and Performance (Profitability \& liquidity), proxied by GP \%, NPM, ROE, current ratio and quick ratio.

The study recommends that finance managers and financial officers of companies should establish a long-term relationship with their suppliers in order to access trade credit in a more easy and fast way, as increased use of trade credit enhances performance of companies through increased profitability. The priority of top management of every company should be to manage their trade credits prudently in order to remain profitable and competitive. It is therefore important know how and what working capital structure will influence their performance.

\section{REFERENCES}

Abor, J. (2005), "The effect of capital structure on profitability: An empirical analysis of listed firms in Ghana", Journal of Risk Finance, 6, 438-47.

Addae, A.A.,Nyarko-Baasi, M., \&Hughes, D. (2013). The Effects of Capital Structure on Profitability of Listed Firms in Ghana (p. 215).

Akinbola, A.O (2012), "Effects of Lease Options as a Source of Finance on the Profitability Performance of Small and Medium Enterprises (SME'S) in Lagos State, Nigeria", International Journal Economic Development Research and Investment, 3, No.3.

Bolton, P. and Freixas, X.: 2000, How can emerging market economies benefit from a corporate bond market?, in E. Borensztein, K. Cowan, B. Eichengreen and U. Panizza (eds), Bond markets in Latin America. On the verge of a big bang?, MIT Press

Bolton, P. \& Scharfstein, D.S. (1996). Optimal Debt Structure and the Number of Creditors, Journal of Political Economy, 104 (1), pp. 1-25.

Brealey, R. (2008). Principles of Corporate Finance. New York: McGraw-Hill.

Bryman, A. and E. Bell (2003). Business Research Methods. Oxford, Oxford University Press.

Charitou, M. S., Elfani, M.\& Lois, P., (2010), The Effect of Working Capital Management on Firm's Profitability: Empirical Evidence From An Emerging Market, Journal of Business \& Economics Research - December, 2010 Volume 8, Number 12

Chebii,E.K.,Kipchumba,S.K. \& Wasike,E.(2011).Relationship Between Firms Capital Structure and Dividend Payout Ratios: Companies Listed at Nairobi Stock Exchange, Kabarak University First International Conference 2011

Crabtree, A. D., and DeBusk, G. K. (2008). The effects of adopting the balanced scorecard on shareholder returns. Advances in Accounting, 24(1), 8-15.

Diamond, Douglas W., Monitoring and Reputation: The Choice between Bank Loans and

Directly Placed Debt," The Journal of Political Economy, Vol. 99(4), August 1991, pp.689-721.

Donaldson, G, (1961), Corporate Debt Capacity: A Study of Corporate Debt Policy and

Determination of Corporate Debt Capacity, Harvard Graduate School of Management, Boston, MA, . Edition Addison Wesley Longman

Duyen, T. H.,(2012) Debts and Profitability An Examination of Manufacturing Firms Listed On Vietnam Stock Exchange

Ebaid, I. E. (2009), "The Impact of Capital-Stucture Choice on Firm Performance: Empirical Evidence from Egypt", The Journal of Risk Finance, 10(5), 477-487.

Eveready East Africa Limited, (2012), Audited Financial Statements for 2012

Fafchamps, M., (1999), Rural Poverty, Risk and Development

Fredericks, J. O. (2001). "Connecting Customer Loyalty to Financial Results." Marketing Management 10(1): 26-32.

Friend, I. \& Lang, L. H. P., An Empirical Test of the Impact of Managerial Self-Interest on Corporate Capital Structure

Government of Kenya Report, 2013

Harash, E., Al-Timim , S., \& Alsaadi, J., (2014), Effects of Financing on Performance of Small and Medium Enterprises, in Iraq. IPASJ International Journal of Management (IIJM), http://www.ipsaj,org/IIJM.htm 
Hyvönen, J. (2007), “ Strategy, performance measurement techniques and information technology of the firm and their links to organization performance" ,Management Accounting Research, 18(3), 343-366.

Iorpev, L., \& Kwanum, I. M. (2012) "Capital Structure and Firm Performance: Evidence from Manufacturing Companies in Nigeria", International Journal of Business and Management Tomorrow, 2 (5), 1-17

Ikechukwu,O. I, (2015, "The Effect of Accounts Payable Ratio on the Financial Performance of Food and Beverages Manufacturing Companies in Nigeria" Quest Journals, Journal of Research in Business and Management Volume 3 Issue 9(2015) pp: 15-21

Ittner, C. D. (2008).Does measuring intangible for management purposes improve firm Performance? A review of the evidence. Accounting \& Business Research, 38(3), 261-272

Jaramillo, F., (2002), Access to Long Term Debt and Effects on Firms' Performance: Lessons from Ecuador

Kajananthan, R., Nimalthasan, P. (2013),“ Capital structure and its impact on firm performance: A study on Sri Lankan listed manufacturing companies" ,Merit Research Journal of Business and Management Vol. 1(2) pp 037-044.

Kajirwa, H. I., (2015), Effects of Debt on Firm Performance: A Survey of Commercial Banks Listed on Nairobi Securities Exchange

Kester, W.C. (1986), "Capital and ownership structure. a comparison of United States and

Japanese manufacturing corporations", Financial Management, Vol. 15 pp.5-16.

Kraus, A. (1973), "A state of preference model of optimal financial Leverage”, Journal of Finance, 911-922

Leonard, M. (2014), "Capital Structure And Financial Performance In Kenya: Evidence From Firms Listed At The Nairobi Securities Exchange", International Journal of Social Sciences and Entrepreneurship, 1 (11), 209-223.

Lopez, J. A., and Saurina J. (2007), “ Determinants of Access to External Finance:

Evidence from Spanish Firms", Working Paper 2007-22. http://www.frbsf.org/publications/ economics/papers/2007/wp07-22bk.pdf

Malm, S., \&Rosland, E. (2013).The Bond-to-Total Debt Ratio and its Impact on Firms' Performance.

Mbugua, E. W., (2010), An Investigation into Application of Pecking Order Concept by Companies Listed at the Nairobi Securities Exchange.

Migiro, S. O. (2005). Small And Medium- Scale Manufacturing Enterprises In Kenya: A Perspective on Alternative Sources of Financing (Master's Thesis).SM

Munene, W. W., (2011), The Effect of Lease Financing on the Financial Performance of Companies Listed At The Nairobi Securities Exchange

Mumias Sugar Company Limited, Audited Financial Statements for year 2013

Mwangi L. W., Makau, M. S., \& Kosimbei G., (2014), Relationship between Capital Structure and Performance of Non-Financial Companies Listed In the Nairobi Securities Exchange, Kenya, Global Journal of Contemporary Research in Accounting, Auditing and Business Ethics (GJCRA)

Myers, S.C. (1984), “The Capital Structure Puzzle”, Journal of Finance, 39, 575-592.

Myers, S. C. and Majluf, N. S (1984)Corporate financing and investment decisions when firms have information that investors do not have", by, Journal of Financial Economics, Vol.13, 1984, pp. $187-221$.

Hassan, U. H., Imran M. M., Amjad M., \& Hussain M., 2014, Effects of Working Capital Management on Firm Performance: An Empirical Study of Non-financial listed Firms in Pakistan

Neokosmidi, Z. V.(2005), “ Advertising, Market Share and Profitability In The Greek Consumer Industry", Journal Of Business \& Economics Research - September 2005: Volume 3, Number 9

Nima, S. S., Mohammad, M. L., Saeed, S., \& Zeinab, T. A. (2012), "Debt Policy and Corporate Performance: Empirical Evidence from Tehran Stock Exchange 
Effects of accounts Payable as Source of Financing on Performance of Listed Manufacturing Firms at the Nairobi Securities Exchange

Companies", International Journal of Economics and Finance, 4 (11), 217-24. http://dx.doi.org/10.5539/ijef.v4n11p217

Nimalathasan, B., Valeriu B. (2010), "Capital Structure and Its Impact on Profitability: A Study of Listed Manufacturing Companies in Sri Lanka (2010)" ,Revista Tinerilor Economisti/The Young Economists Journal 13,55-61

Pandey, I. M. (2005). Financial Management (Vol. Ninth Edition): Vikas Publishing House PVT LTD.

Pouraghajan, A. (2012). The Relationship between Capital Structure and Firm Performance Evaluation Measures: Evidence from the Tehran Stock Exchange (pp. 168-169). N.p.: Published by Asian Society of Business and Commerce Research. Retrieved from www.ijbcnet.com

Pratheepkanth, P. (2011). Capital Structure and Financial Performance: Evidence from

Selected Business Companies in Colombo Stock Exchange Sri Lanka. Journal of Arts, Science \& Commerce, 2, 171- 82

Quainoo, T. K., (2011), Examining the Impact of Loans on SMEs in Ghana

Rajan, R.G., \& L. Zingale, (1995), "What do we know about capital structure? Some

evidence from international data", The Journal of Finance, No. 50, pp. 1-58.

Rajan, R.,1992. "Insiders and Outsiders: The Choice Between Informed and Arm's Length Debt," Journal of Finance, 47, 1367-1400.

Reichheld, F. F. (2004). The One Number You Need to Grow. Harvard Business Review, Harvard Business School Publication Corp. 82: 133-133

Safaricom Limited, Audited Financial Statements for 2012, 2013

Salam, A. (2013). Effects of Lease Finance on Performance of SMEs in Bangladesh. Retrieved from ISSN (Online): 2319-7064

Saleemi, N. A. (2009). Entrepreneurship Simplified .N.A. Saleemi Publications, Nairobi Kenya.

Shawn, C. (2009). External Finance. Nairobi Kenya: N.A Saleemi Publications.

Siro, (2011), The Effect of Capital Structure on Financial Performance of Firms Listed at The Nairobi Securities Exchange

Uchumi Supermarkets \& Subsidiaries Financial Statements for year 2013

Vandermerwe, S. (2000), "How Increasing Value to Customers Improves Business Results."Sloan Management Review 42(1): 27-37.

Wald, J. (1999), "How firm characteristics affect capital structure: an international Comparison", The Journal of Financial Research, Vol. 22 No.2, pp.161-87.

\section{AUTHOR'S BIOGRAPHY}

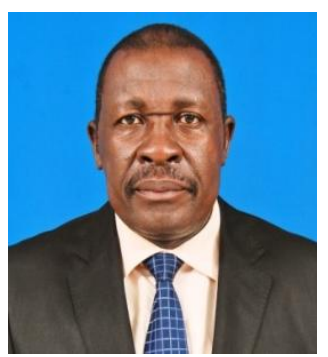

Benjamin Malingu Achode, is a Certified Public Accountant of Kenya, an accredited Governance Auditor and is also a Certified Public Secretary of Kenya. He is a Co-founder of Achode and Company, a firm of Certified Public Accountants of Kenya and has been a practicing Accountant since 1996 to date. He previously worked for Price Waterhouse (now PricewaterhouseCoopers) in Audit Department and for Unilever, Kenya as Commercial Manager. He is a consultant on financial, tax, audit and company secretarial matters for commercial enterprises, unincorporated businesses and non-governmental entities. Benjamin Achode is currently pursuing Executive Master of Business Administration degree at Jomo Kenyatta University of Agriculture and Technology, Kenya. He is married with four children and two grandsons. 